\title{
Variation of the Muscle Protein in Horse Mackerel
}

\author{
Taneko SuzukI*, Koichi KannA*, and Tuneji Yamamoto** \\ (Received January 30, 1969)
}

It has been reported that the species specific post-mortem changes in the physicochemical properties of myofibrillar protein of fish can be classified into two types: $:^{1 \sim 21}$ the protein of some species hardly changes after death, while that of the other species changes easily as the post-mortem time progresses. The previous paper ${ }^{3 \prime}$ revealed that the properties of myofibrillar protein from horse mackerel fell somewhere between the above mentioned two types. However, experiments in a further study of the muscle protein of horse mackerel showed different results by samples occasionally. It was assumed that the variation of the study results might be due to the difference of fishing ground, method and season. The present study was carried out to find out if the variation of the properties of the protein had something to do with fishing ground, method and season.

\section{Experimental}

Material. The fishing grounds, methods and seasons of the samples of horse mackerel, Trachrus japonicus, are shown in Table 1. The white muscle of each fish was subjected to the following analyses. In some cases of the determination of fish jelly forming ability, the muscles from the same lot of fish were used as described below.

Extraction of protein. The minced muscle was added to 5 volumes of the cold $0.6 \mathrm{M}$ $\mathrm{KCl}$ solution, homogenized in a Waring Blender and centrifuged at 7,000 r.p.m. for 30 minutes.

Ultracentrifugal analysis. One $\mathrm{ml}$ of the above $0.6 \mathrm{M} \mathrm{KCl}$ extracts containing 1-1.2 mg protein nitrogen was used. The ultracentrifugal schlieren patterns were observed by a Hitachi ultracentrifuge at 50,000-60,000 r.p.m. for 60 minutes.

Protein concentraction. The biuret reaction described by UMEMOTO $^{4)}$ was used. The values were standardized by the micro KJELDHAL method.

Flow birefringence. The $0.6 \mathrm{M} \mathrm{KCl}$ extracts were centrifuged at 12,500 r.p.m. for 30 minutes and the flow birefringence of the supernatant was measured qualitatively by a simple apparatus designed by OKADA. ${ }^{\text {; }}$

Fish jelly forming ability. Fifteen grams of minced white muscle taken from the same

東海区水研業績 B505.

* Tokai Regional Fisheries Research Laboratory, Kachidoki, Chuo-ku, Tokyo (鈴木た权子・神名孝一： 東海区水㢈研究所).

** National Federation of Fish Jelly Processing Cooperative Association of Japan, Kanda Sakumacho, Chuo-ku, Tokyo (山本常治：全国加委に゙こ水鷹加工業協同組合連合会). 
Table 1. Description of samples used.

\begin{tabular}{|c|c|c|c|}
\hline Exp. No.* & Fishing date & Fishing ground & Number of sample \\
\hline 0 & Apr., 1966 & Sagami Bay & 2 \\
\hline $0 \quad 2$ & Jun., " " & $"$ & 5 \\
\hline 0 & Jul., " ", & " & 10 \\
\hline 0 & Jul., ", & " & 17 \\
\hline$\triangle$ & Jul., ", & Goto & 2 \\
\hline 0 & Oct., 1967 & Sagami Bay & 17 \\
\hline$\Delta$ & Mar., 1968 & Tushima & 14 \\
\hline$\triangle$ & Mar., ", & ", & 13 \\
\hline$\triangle 9$ & Apr., " & East China Sea & 19 \\
\hline$\triangle 10$ & May, " " & " & 21 \\
\hline$\times \quad 11$ & Jun., " & Choshi & 5 \\
\hline$\bigcirc \quad 12$ & Sept., " & Sagami Bay & 15 \\
\hline$\bigcirc \quad 13$ & Sept., " & $\begin{array}{l}\text { Kamogawa } \\
\text { (Chiba Prefecture) }\end{array}$ & 18 \\
\hline
\end{tabular}

* Fishing method: $\bigcirc$ Set net, $\triangle$ Purse seine, $\times$ Unknown

lot of fish was agitated with 5 volumes of the water containing $0.2 \%$ pyrophosphate for 10 minutes and the water was discarded. The treatment was repeated five times and then $0.5 \% \mathrm{NaCl}$ solution was added to the washed muscle in order to promote the separation of meat from water. After the $\mathrm{NaCl}$ solution was removed by hand-pressing, the muscle was added with $\mathrm{NaCl}$ in the amount of $3 \%$ to the total weight before grinding. The ground muscle was stuffed into a weight bottle and was steamed at $85-90^{\circ} \mathrm{C}$ for 45 minutes, and the strength of the jelly thus formed was determined by gelometer. For determining the jelly forming ability of each fish, $5 \mathrm{~g}$ of the minced muscle was ground with $150 \mathrm{mg}$ of $\mathrm{NaCl}$ and stuffed into a weight bottle and steamed at $85-90^{\circ} \mathrm{C}$ for 30 minutes, and then the jelly strength was observed organoleptically.

Crude fat in the muscle. Ten grams of muscle was ground with $20 \mathrm{~g}$ of Glauber's salt in a morter, mixed well with $30 \mathrm{ml}$ of diethylether and allowed to stand for $24 \mathrm{hrs}$, and the ether was filtered off. The extraction was repeated several times. After the extracts were combined, the ether was distilled off, and the residue was weighed.

\section{Results and Discussion}

In the ultracentrifugal schlieren patterns of myofibrillar protein, four different types of post-mortem changes are observed as shown in Fig. 1. Each pattern was named for convenience as follows:

Type 0. Myofibrillar protein from any of the bottom and pelagic fish so far tested shows this type of change as the post-mortem time progresses: the peak of actomyosin becomes lower and broader, and the sedimentation velocity increases with the progress of 


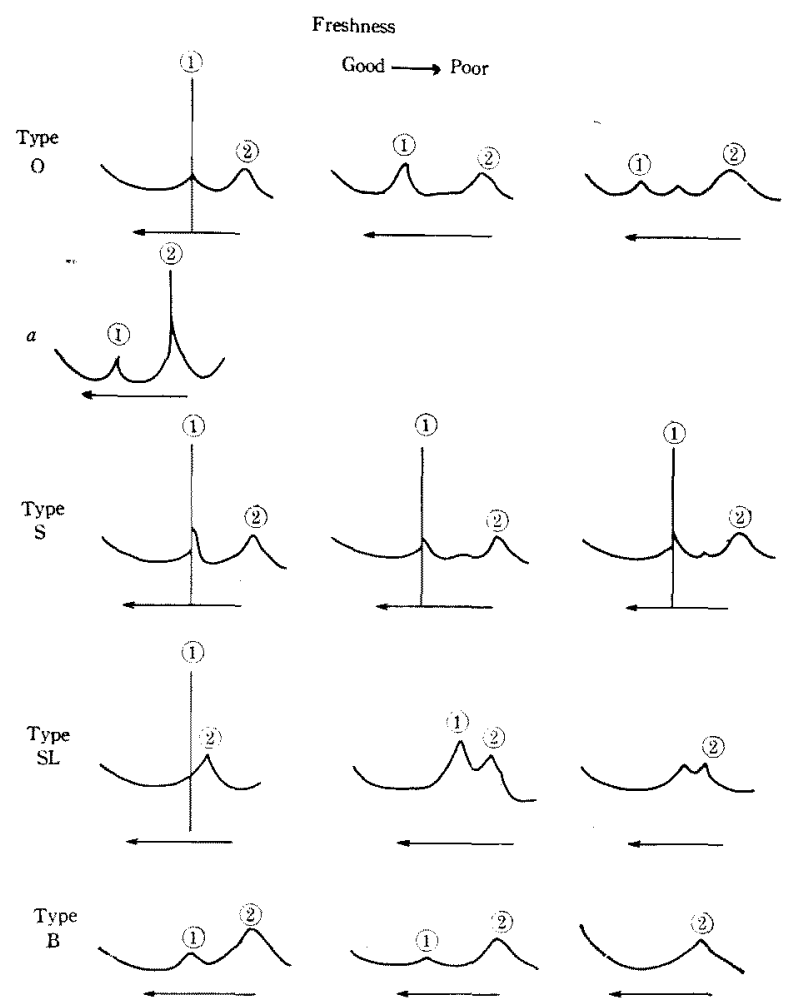

Fig. 1. Type of ultracentrifugal pattern of $0.6 \mathrm{M} \mathrm{KCl}$ extracts from horse mackerel.

(1) Actomyosin (2) Myosin

time after death of the fish.

Type S. The peak of actomyosin remains very sharp and the sedimentation velocity is almost constant for a longer time after death of the fish.

Type SL. Since the sedimentation velocity of actomyosin is very slow, the peak of actomyosin partly overlaps with that of myosin. As the time progresses after death of fish, the peak of actomyosin becomes low and broad, but the sedimentation velocity of actomyosin is unchanged.

Type B. Even in a very fresh muscle, the peak of actomyosin is broad and low, but almost disappears after the muscle is aged.

Usually the peak of actomyosin is sharper and higher than that of myosin when the muscle is fresh. When the muscle is very fresh, it is often found that the peak of myosin is sharper and higher than that of actomyosin as shown in Fig. 1a. It is assumed that the occurrence of such a pattern depends on the content of ATP in the muscle, since actomyosin may be dissociated into actin and myosin when the ATP level is high in the muscle. 
Table 2. Relation between the rate of flow birefringence and the type of ultracentrifugal pattern of $0.6 \mathrm{M} \mathrm{KCl}$ extracts.

\begin{tabular}{|c|c|c|c|}
\hline $\begin{array}{l}\text { Freshness } \\
\text { Type }\end{array}$ & Pre-rigor & In rigor & $\begin{array}{c}\text { Post-rigor } \\
\text { (Poor) }\end{array}$ \\
\hline o & m & H & + \\
\hline$S$ & m & 曲 & HWH \\
\hline $\mathrm{SL}$ & HA & H & + \\
\hline B & - & - & - \\
\hline
\end{tabular}

Table 2 shows the relative intensity of the flow birefringence in each type. The flow birefringence of the myofibrillar protein solution showing Type $\mathrm{S}$ remains strong, even the freshness of muscle decreases. In the case of Type O or SL, however, the intensity of the flow birefringence decreases as the post-mortem time progresses. The flow birefringence is not observed in Type B regardless of the freshness of muscle.

Table 3. Relation between the fish jelly forming ability and the type of ultracentrifugal pattern.

\begin{tabular}{c|c|c|c}
\hline Freshness & Pre-rigor & In rigor & $\begin{array}{c}\text { Post-rigor } \\
\text { (Poor) }\end{array}$ \\
\hline Type & $H$ & + & \pm \\
S & $H$ & $+H$ & +1 \\
SL & $H$ & + & + \\
B & - & - & - \\
\hline
\end{tabular}

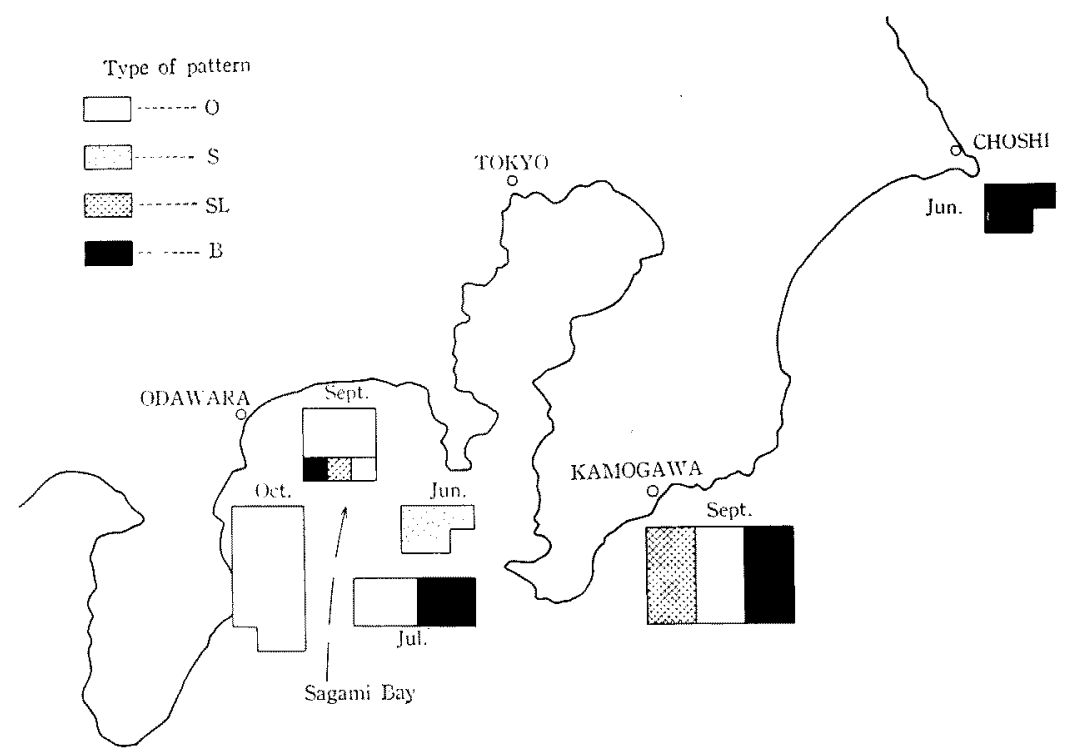

Fig. 2. Type of ultracentrifugal pattern of $0.6 \mathrm{M} \mathrm{KCl}$ extracts from horse mackerel in various fishing grounds. 
Table 3 shows the relation between the type of ultracentrifugal pattern and the jelly forming ability. From the fish showing Type $\mathrm{O}$ or SL in the ultracentrifugal analysis, jelly with very high strength can be produced only when the muscle is fresh, while from the fish showing Type S, jelly with very high strength can be obtained even if the muscle is not fresh. On the contrary, the fish showing Type B can not produce any jelly however fresh the muscle may be.

Researches were made if these types of ultracentrifugal pattern were related to fish caught in different fishing grounds and seasons. The results are shown in Figs. 2 and 3. There is no clear relationship between the type and the fishing ground or season. It is found that the fish caught in the East China Sea or around Tushima show Type B more often than the fish from Sagami Bay. In order to investigate if such differences in the muscle properties are related to the growth rate, the relationship between the body length and ultracentrifugal pattern was plotted (Fig. 4). Since immature fish show all of the four kinds of ultracentrifugal patterns, no relationship can be observed between them.
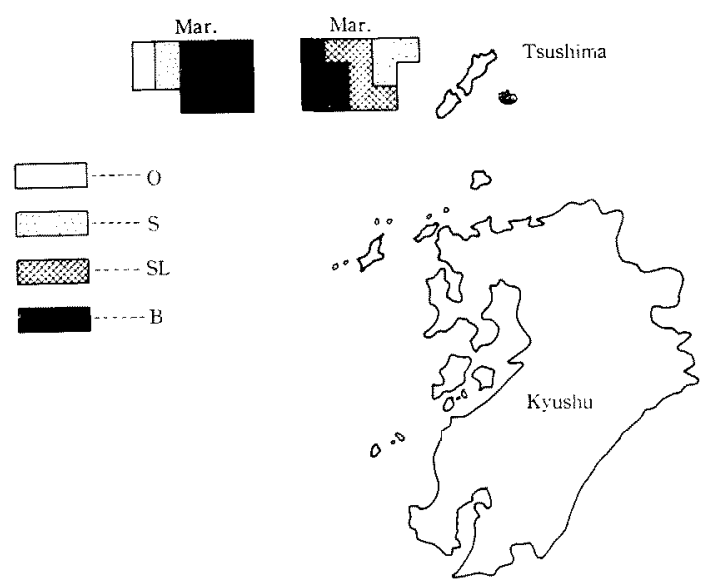

East China Sea
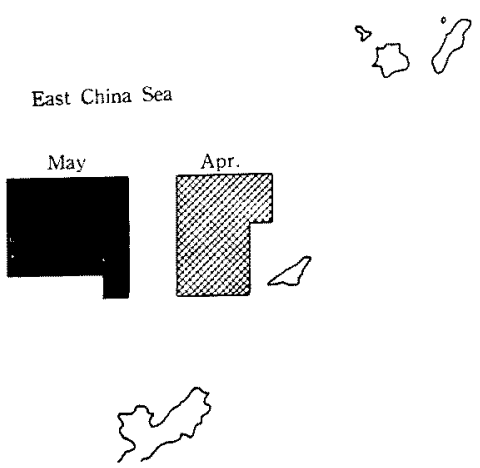

Fig. 3. Type of ultracentrifugal pattern of $0.6 \mathrm{M} \mathrm{KCl}$ extracts from horse mackere! in various fishing grounds. 


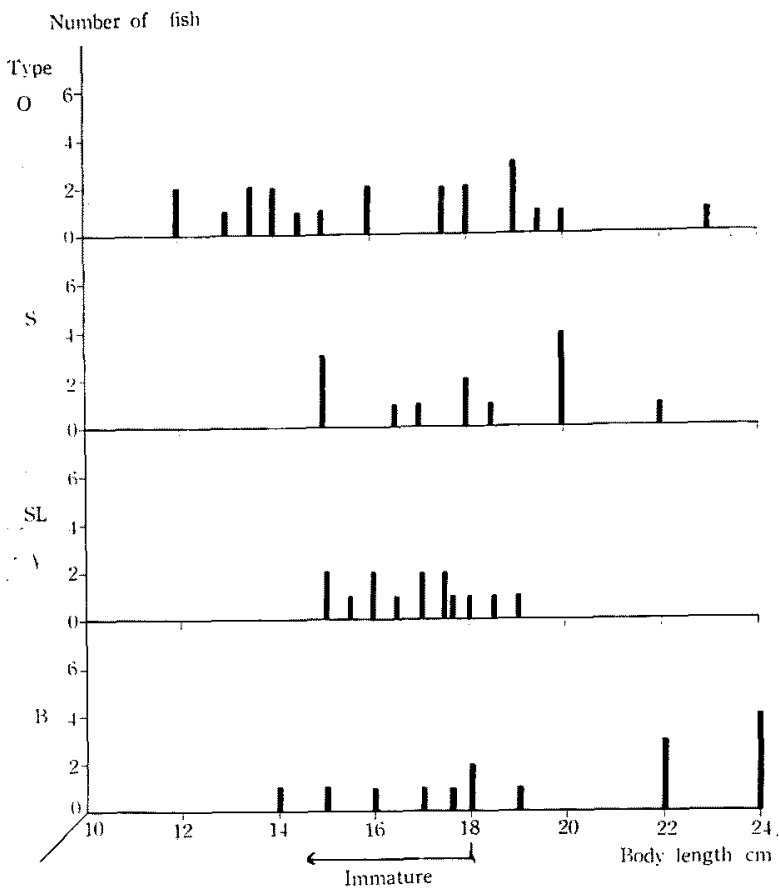

Fig. 4. Relation between the type of ultracentrifugal pattern and body length.

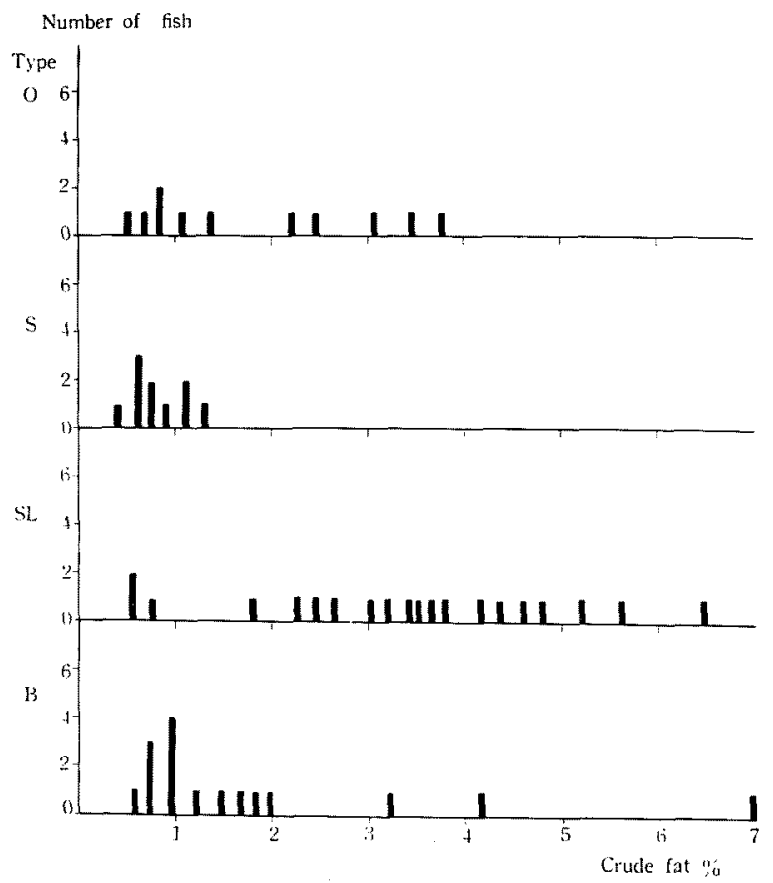

Fig. 5. Relation between the type of ultracentrifugal pattern and crude fat content. 
Figure 5 shows the relationship between the crude fat content of muscle and the type of the ultracentrifugal pattern. Although the muscle of Type $S$ seems to contain smaller amount of fat than that of the others, no definite conclusion can be obtained, since the number of samples is not enough.

Types $\mathrm{B}$ and $\mathrm{O}$ are observed in the fish killed with narcosis on board our fishing boat, while all of four types are found in the fish caught by any fishing method. Therefore, fishing method has nothing to do with the ultracentrifugal characteristics of horse mackerel protein.

Table 4. Jelly forming ability of various materials.

\begin{tabular}{l|rrrr|c|c|c}
\hline \multirow{2}{*}{ Fishing ground } & \multicolumn{3}{|c|}{ Number of fish* } & \multicolumn{4}{|c}{ Jelly strength } \\
\cline { 2 - 7 } & O & S & SL & B & Very fresh & Fresh & Poor \\
\hline Sagami Bay & 10 & 2 & 2 & 1 & 642 & 897 & 567 \\
Tushima & 0 & 4 & 4 & 6 & - & - & 220 \\
" & 2 & 2 & 2 & 9 & - & - & 160 \\
East China Sea & 0 & 0 & 19 & 0 & - & - & 170 \\
\hline
\end{tabular}

* The jelly was prepared from the mixture of fish meat having different ultracentrifugal patterns

Many makers of frozen surimi (fish meat paste) have indicated that there are two kinds of horse mackerel from the view point of the meat properties. The present study proves that what makers said is reasonable to some extent. The smaller quantity of mixture of Type B in a lot produces, better fish jelly as shown in Table 4. It is very difficult to distinguish these different types of horse mackerel by their external appearance. The reason why horse mackerel has many variation in the properties of the muscle protein is still unknown. It is questionable whether or not horse mackerel with different properties of the muscle described above contains actually different kinds of protein. One hypothesis may be framed that the protein from each horse mackerel has the same physico-chemical properties but some cathepsin contained in the muscle has different activity, so that it may affect the muscle protein in different ways.

\section{Summary}

Ultracentrifugal pattern and the rate of flow birefringence of $0.6 \mathrm{M} \mathrm{KCl} \mathrm{extracts} \mathrm{from}$ the muscle of horse mackerel were determined, and the jelly forming ability of the fish meat was also measured.

In the experiment, different types of the muscle in the postmortem changes have been found: the protein changes as the progress of time after death of the fish, and the jelly with very high strength can be produced only when the muscle is fresh; the protein hardly changes for a long time after death of the fish and jelly with very high strength can be obtained even if the muscle is unfresh; on the contrary, the protein changes easily and any jelly can not be produced even if the muscle is fresh. 
There was no clear relationship between the above mentioned properties of the muscle and fishing ground, season or method.

\section{References}

1) T. Suzukr and M. Migrta: This bull., 28, 61-72 (1962).

2) T. SuzUKi and K. KanNa: ibid., 32, 590-599 (1966).

3) Y. Maruyama and T. SuzukI: ibid., 34, 415-419 (1968).

4) S. UMEMOTo: ibid., 32, 427-435 (1966).

5) M. OKADA and S. TADA: ibid., 20, 224-231 (1954). 